\title{
A NEW APPROACH TO INNOVATION AND ITS APPLICATION TO THE COUNTRIES OF THE EUROPEAN UNION ${ }^{1}$
}

\author{
Manuel Agüeros, Pedro Casares-Hontañón, Pablo Coto-Millán \\ Department of Economics, University of Cantabria, Spain \\ Pablo De Castro, Miguel Ángel Pesquera \\ Department of Transport, University of Cantabria, Spain
}

Manuscript received: January 15, 2012

Revised version: March 8, 2013

\begin{abstract}
Agüeros M., Casares-Hontañón P., Coto-Millán P., De Castro P., Pesquera M.Á., 2013. A new approach to innovation and its application to the countries of the European Union. Quaestiones Geographicae 32(2), Bogucki Wydawnictwo Naukowe, Poznań, pp. 5-14. 4 tables, 4 figs. DOI 10.2478/quageo-2013-0009, ISSN 0137-477X.

ABSTRACT. This research provides a new theoretical approach to innovation. Innovation relies on collaborative relationships between universities, private companies and public administration. This theoretical approach offers an opportunity for scientific discovery in an environment of collaboration. Innovative ideas are not self-contained items; they are more like ecosystems and networks. The article also provides data processed in recent years (2003-2009) for the European Union states, providing relevant empirical evidence on the relationship between human capital, relational capital, technological capital and innovation. In the econometric and statistical modelling, the countries of the Europe of the Fifteen (EU-15) will be considered.
\end{abstract}

KEY WORDS: relational capital, human capital, technological capital, innovation, European Union

Pablo Coto-Millán, Department of Economics, University of Cantabria, Avd/ Los Castros s/n, Santander, Spain; e-mail: cotop@unican.es

\section{Introduction}

This research studies the role that human capital and relational capital play in innovation. To this end, we use a general model for innovation composed by one basic equation that has human capital, technological capital and relational capital as endogenous variables in order to explain

1 This research was supported financially by the European Regional Development Fund under the project Dissemination and Networks of Knowledge in the Atlantic Arc (K-Networks). innovation. The creative mixture of these three elements generates technological innovation. The process is based upon the assumption that relational, cultural and regional institutional factors contribute to a better understanding and support of human and technological capital, eventually working on innovation.

The adopted model will be estimated using robust econometric techniques from the available data panel for the period 2003-2009 on the variables involved for the countries belonging to the Europe of the Fifteen (EU-15). Estimations of the 
model will then be compared for several alternative definitions of human capital, technological capital and relational capital (open innovation and in-house innovation), the comparison being made by their impact on innovation production. Finally, factors bearing on the production of human, technological and relational capital and the generation of innovation among European countries will be analysed in detail, and some conclusions will be extracted from the results obtained.

\section{Literature review}

The role of human and technological capital in the innovation process has been a topic of increasing interest and discussion among economists, geographers and other social researchers. Some of the most outstanding studies of those issues are listed below. At the beginning of economic theory it was thought that regional or national natural resources were the main factor of growth. Subsequently, natural resources were replaced by all kinds of infrastructure, mainly for transport, human-made. With the industrial revolution and the subsequent theories of Solow (1956, 1957), technological progress becomes a key explanatory factor. Nowadays, after the major contributions by Lucas (1988), we tend to think that the main factor of growth is human capital, understood in a fairly broad sense. When talking about human capital we should not think exclusively of education, experience and skills of the workforce; rather, innovative capacity and human values should also be considered. Even in line with the New Institutional Economics, we can think of the quality of institutions as a reason for economic growth. Basically these are factors of modern growth theory, especially those developed from the mid-1980s until today. Furthermore, in this regard, Solow's (1970) work stands out, which highlights the relevance of the effect of technological change on economic growth.

The studies by Jacobs $(1961,1969)$ focused on the transference of knowledge in cities. In her reasoning, cities played a crucial role in economic development through interactions among people and the generation of new products and new technologies.
Later, Romer (1986, 1987, 1990) establishes the connection between knowledge, human capital and economic growth through his endogenous economic growth model, arguing that investments in human capital create externalities and increasing returns.

The seminal endogenous regional model of Lucas (1988) considers cities as transferring knowledge and generating powerful human externalities that increase productivity and boost economic growth.

The connection between human capital and regional growth is also supported by a large body of empirical evidence studied at national and regional levels. In the same thread of thought, recent research (Barro 1991, Black \& Henderson 1998, Eaton \& Eckstein 1997, Glaeser 1998, 1999, 2000a, 2000b, Glaeser et al. 1995, 2001, Glendon 1998, Rauch 1993, Simon 1998, Shapiro 2006, Young 1998) has tested Lucas' hypotheses empirically, stressing the role of human capital and economic growth.

Berry \& Glaeser's (2005) work highlights the growing gap in the levels of human capital among regions in the USA over the past decades.

Finally, Florida (2002a, b, c, 2005a, b, 2006), Stolarick \& Florida (2006), Florida et al. (2010a, b) and Mellander \& Florida (2011) advocate the need to better understand the factors that generate innovation. They have created a new concept of relational capital which enables territories to attract talent. Further, they conclude that innovation operates as a dynamic flow rather than as a static stock.

This paper argues that the key factors are collaborative relations existing among universities, private companies and public administration. In line with Leydesdorff's (2005) triple helix model, Warren et al. (2010) and Roth et al. (2011) consider that the university provides a foundation of human capital, scientifically trained, that, when adequately related to private enterprise, can generate open innovation. However, it is still necessary in the relationship between private companies and public administration to implement a discovery and make it real. In these circumstances, the link and liaison between human and technological capital is relational capital, and the link is collaborative and appropriate when it is performed with innovation. 


\section{The model}

\subsection{Structure}

To shed light on these issues, we developed a general model of innovation for European countries, with the aim of isolating and analysing the independent effects of human capital, technological capital and relational capital on innovation.

A schematic representation of the general model of innovation is shown in Fig. 1. The arrows identify the hypothesised structure of relationships between the key variables.

Next, we will proceed to estimate the contribution of human capital, technological capital and relational capital. We will use an aggregated production function whose variable to be explained is innovation or throughput, its explanatory variables being the three defined production factors, viz. human capital, technological capital and relational capital. Such a function will be of the type:

$$
\begin{aligned}
& \mathrm{f}\left(\mathrm{y}_{1}, \mathrm{y}_{2}, \mathrm{y}_{3}\right)=\mathrm{I}=\gamma \mathrm{y}_{1}^{\alpha_{1}} \mathrm{y}_{2}^{\alpha_{2}} \mathrm{y}_{3}^{\alpha_{3}} ; \\
&\left(\gamma>0, \alpha_{1}>0\right)
\end{aligned}
$$

In this equation, innovation is represented by $I$, and it is explained by three production factors as the effect of human capital, represented by $y_{1}$, investment in technological capital, represented by $y_{2}$, and investment in relational capital, which will be called $y_{3}$. Formula (1) will now take logarithms, obtaining the following form:

$$
\begin{aligned}
\log \mathrm{I}_{\mathrm{i}, \mathrm{t}}= & \gamma+\alpha_{1} \log \mathrm{y}_{1, \mathrm{i}, \mathrm{t}}+\alpha_{2} \log \mathrm{y}_{2, \mathrm{i}, \mathrm{t}}+ \\
& +\alpha_{3} \log \mathrm{y}_{3, \mathrm{i}, \mathrm{t}}+\varepsilon_{\mathrm{i}, \mathrm{t}}
\end{aligned}
$$

where $\varepsilon_{i, t}$ represents errors in the econometric estimation, while the rest of the variables are as defined previously.

The model helps to unravel the way of production in an innovation approach. It also enables a simulation and analysis of the effect of relationships (relational capital) as moulded by various institutional and regional cultural factors - for example, universities or private companies, and the empathy and support of public administration - on the geographical distribution of innovation.

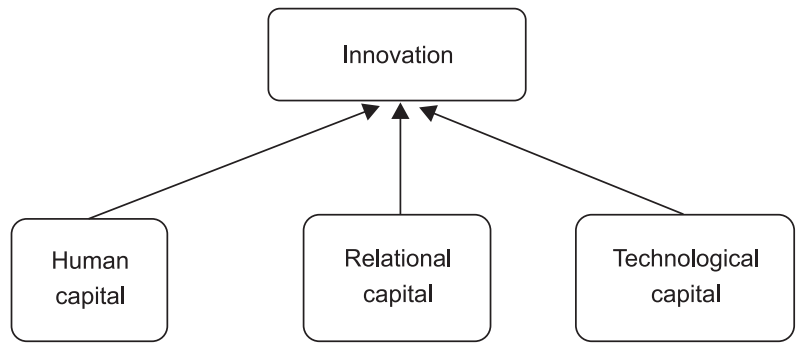

Fig. 1. Structure of the relationship of variables. Source: own elaboration.

We have also included the innovation index from Eurostat. This is an indicator based on the number of patents registered and applied by the EPO (European Patent Office) per million of the population, our source being Eurostat and the European Innovation Scoreboard.

This paper will use a set of econometric and statistical techniques of panel data regression of human capital, technological capital, relational capital and innovation, in terms of the number of patents, in order to study the nature of the causal relations between the variables in the model described above.

\section{The data}

In 2001, the European Commission, in order to track innovation in Europe, suggested performing an annual report with innovation indicators and their economic effects (European Innovation Scoreboard, EIS). Thus, each year there were annual reports with indicators by country (from 2003 to 2009), with 31 indicators. Also, every two years (2004-2008) 15 indicators were created sorted by European regions. In this paper, a comparison of the EU-15 countries is carried out using data extracted from these reports, the main sources of which are the Eurostat databases.

\subsection{Human capital}

As previously mentioned, to obtain an index of human capital in the EU-15, two indices were combined: population aged 25 to 64 with tertiary education (human capital 1) and share per 100 people between 25 and 64 involved in the learning processes throughout their life (human capital 2). All human capital data were extract- 
ed from the Eurostat and European Innovation Scoreboard databases, and scaled from 0 to 10 points.

Table 1 and Fig. 1 show that the magnitudes for the European countries analysed reach both the synthetic index of European human capital and the simple indices that compose them.

It is worth noting the following results:

1) The leading countries in terms of the synthetic index of human capital are Finland, Sweden, Denmark and the United Kingdom. Three other nations - Ireland, The Netherlands and France - also attain very high scores.

2) Two countries obtain the highest scores in doctoral programmes (human capital 1) France and Ireland, closely followed by Denmark and the United Kingdom.

3) Two countries stand out in college graduates (human capital 2) - Finland and Sweden, fol-
Table 1. European indices for human capital in the EU-15.

\begin{tabular}{|l|c|c|}
\hline \multicolumn{1}{|c|}{ Rank } & Human capital & Human capital \\
\hline 1. Finland & $\mathbf{1}$ & $\mathbf{2}$ \\
\hline 2. Sweden & 7.4 & 10 \\
\hline 3. Denmark & 2.9 & 8.7 \\
\hline 4. United Kingdom & 5.5 & 9.4 \\
\hline 5. Ireland & 3.6 & 8.7 \\
\hline 6. Netherlands & 2.9 & 9.3 \\
\hline 7. France & 4.0 & 8.8 \\
\hline 8. Belgium & 3.0 & 7.5 \\
\hline 9. Luxembourg & n.a. & 8.8 \\
\hline 10. Portugal & 10.0 & 7.6 \\
\hline 11. Austria & 5.3 & 3.9 \\
\hline 12. Germany & 5 & 4.9 \\
\hline 13. Spain & 2.1 & 6.9 \\
\hline 14. Italy & 3.0 & 8.0 \\
\hline 15. Greece & 1.6 & 3.9 \\
\hline
\end{tabular}

Source: own elaboration (European Innovation Scoreboard and Eurostat data, 2009).

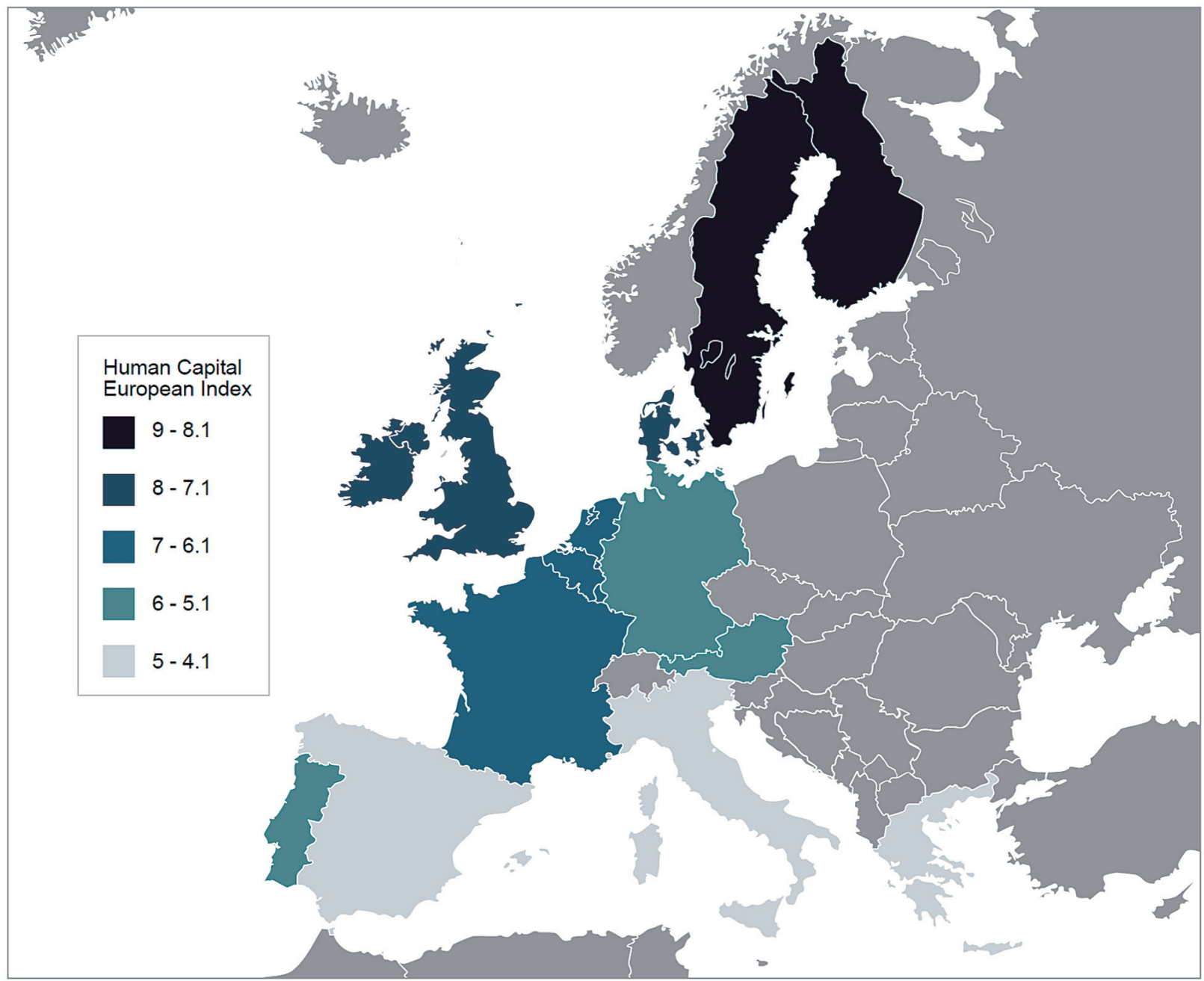

Fig. 2. Human capital European index of the EU-15. Source: own elaboration. 
lowed by the United Kingdom, Austria and Germany.

\subsection{Technological capital}

The following indicators were used to obtain the synthetic index of technological capital: \% of GDP for public expenditure on R\&D (technological capital 1) and \% of GDP for private credit (technological capital 2). The data concerning technological capital 1 were extracted from the Eurostat databases, while those for technological capital 2 from the International Monetary Fund's International Financial Statistics. The data were scaled from 0 to 10 points.

Table 2 and Fig. 3 show the magnitudes of the European countries analysed that reach the syn-
Table 2. European indices for technological capital in the EU-15.

\begin{tabular}{|l|c|c|}
\hline \multicolumn{1}{|c|}{ Rank } & Tech capital 1 & Tech capital 2 \\
\hline 1. Sweden & 8.5 & 5.9 \\
\hline 2. Denmark & 7.1 & 10.0 \\
\hline 3. Finland & 8.2 & 3.9 \\
\hline 4. United Kingdom & 5.5 & 9.6 \\
\hline 5. Netherlands & 6.4 & 8.8 \\
\hline 6. Germany & 6.9 & 4.9 \\
\hline 7. Austria & 6.8 & 5.4 \\
\hline 8. Spain & 5.4 & 9.0 \\
\hline 9. Ireland & 4.1 & 9.9 \\
\hline 10. France & 6.3 & 4.9 \\
\hline 11. Belgium & 5.1 & 4.3 \\
\hline 12. Luxembourg & n.a. & n.a. \\
\hline 13. Italy & 4.8 & 4.8 \\
\hline 14. Portugal & 5.5 & 8.2 \\
\hline 15. Greece & 3.6 & 4.2 \\
\hline
\end{tabular}

Source: Own elaboration (European Innovation Scoreboard, Eurostat and IFM data, 2009).

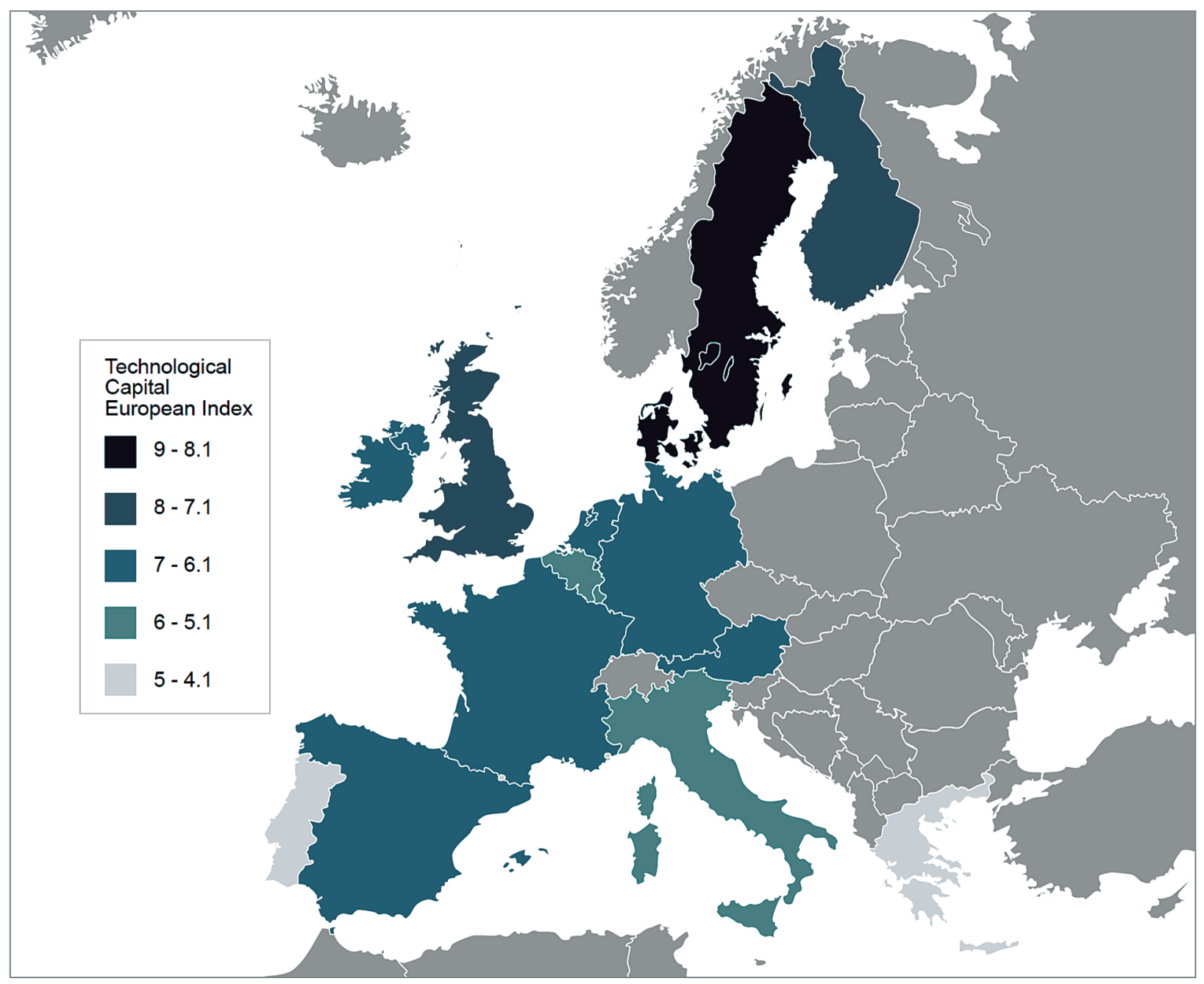

Fig. 3. Technological capital European index of the EU-15. Source: own elaboration. 
thetic index of technological capital as well as the different simple indices that compose them.

The main results obtained in relation to technology are:

1) In the sample of the European countries studied, Sweden, Denmark, Finland and the United Kingdom occupy the first positions in the technological capital ranking, measured by the synthetic indicator.

2) Seven other countries are reasonably well located in relation to the synthetic indicator of technology. Those are The Netherlands, Germany, Austria, Spain, Ireland, Belgium, and France.

3) In the last positions of the technological ranking we find Italy, Portugal and Greece.

\subsection{Relational capital}

The synthetic index of relational capital is obtained from the following two indicators: sum of small and medium-sized enterprises with inhouse innovation activities (relational capital 1), and sum of small and medium-sized enterprises with innovation activities in collaboration with other companies and institutions over the three previous years. This indicator is a proxy of open innovation (relational capital 2). All the relational capital data were obtained from the Eurostat and European Innovation Scoreboard databases, being scaled from 0 to 10 points.

Table 3 and Fig. 4 show the magnitudes of those European countries analysed that reach the synthetic index of relational capital as well as the different simple indices that compose them.

The main results obtained for the relational capital of the nations studied are:

1) Finland, Denmark, Austria and The Netherlands occupy the top positions, while Germany, Ireland, Sweden and the United Kingdom follow them closely.

2) It should be noted that regarding relational capital, Spain, Italy and Belgium occupy the last positions.

3) The other countries are in the intermediate section.
Table 3. European indices for relational capital in the EU-15.

\begin{tabular}{|l|c|c|}
\hline \multicolumn{1}{|c|}{ Rank } & $\begin{array}{c}\text { Relational } \\
\text { capital 1 }\end{array}$ & $\begin{array}{c}\text { Relational } \\
\text { capital 2 }\end{array}$ \\
\hline 1. Finland & 8.8 & 10.0 \\
\hline 2. Germany & 9.9 & 3.3 \\
\hline 3. Denmark & 8.8 & 5.4 \\
\hline 4. Austria & 8.9 & 6.5 \\
\hline 5. Netherlands & 5.9 & 4.5 \\
\hline 6. Ireland & 8.4 & 4.3 \\
\hline 7. Sweden & 9.0 & 6.0 \\
\hline 8. United Kingdom & 6.6 & 6.6 \\
\hline 9. France & 6.1 & 4.2 \\
\hline 10. Greece & 7.1 & 4.8 \\
\hline 11. Portugal & 7.4 & 2.4 \\
\hline 12. Luxembourg & n.a. & 5.5 \\
\hline 12. Spain & 5.3 & 1.8 \\
\hline 13. Italy & 6.1 & 1.6 \\
\hline 14. Belgium & 3.3 & 1.4 \\
\hline
\end{tabular}

Source: Own elaboration (European Innovation Scoreboard and Eurostat data, 2009).

\subsection{Variables used in the model}

The variables used in the model are as follows:

- Dependent variable: innovation

The dependent variable used in the model to approach production is the innovation index, or an index of innovations implemented in the real world; the proxy used is the number of patents in the EPO (European Patents Office). The independent variables are as follows:

- Human capital

To represent talent, we considered the human capital index as the traditional or conventional indicator of human capital, measured, as mentioned, by the combination of two indices: population aged 25 to 64 with tertiary education (human capital 1) and share per 100 people between 25 and 64 involved in the learning processes throughout their life (human capital 2).

- Technological capital

A technological variable is included in order to take into account the independent effect of technology on regional development. Besides, the effect of each of the indicators used is studied to obtain the technological capital index. The composite index of technological capital is the average \% of GDP for public expenditure on R\&D (technological capital 1) 
and $\%$ of GDP for private credit (technological capital 2).

Apart from using a technological platform with human capital, it is still necessary to account for the existence of a collaborative environment of institutions and people, that is, relational capital is needed, providing innovation. Up to the present moment, it has not been proved that innovation is associated with variables such as the degree of empathy between private companies and universities, public administration support, and the development of collaborative services. Measures of the relational capital variable will be included in our model and analysis.
- Relational capital

Thus, relational capital is included, understood not only as a reduction of barriers to collaboration of human capital, but also to collaboration among businesses and between businesses and other entities. Relational capital within regions and a concentration of these factors create an economic, social and cultural environment more open to innovation. Two indices are used: sum of small and medium-sized enterprises with in-house innovation activities (relational capital 1) and sum of small and medium-sized enterprises with innovation activities in collaboration with other companies and institutions over the three pre-

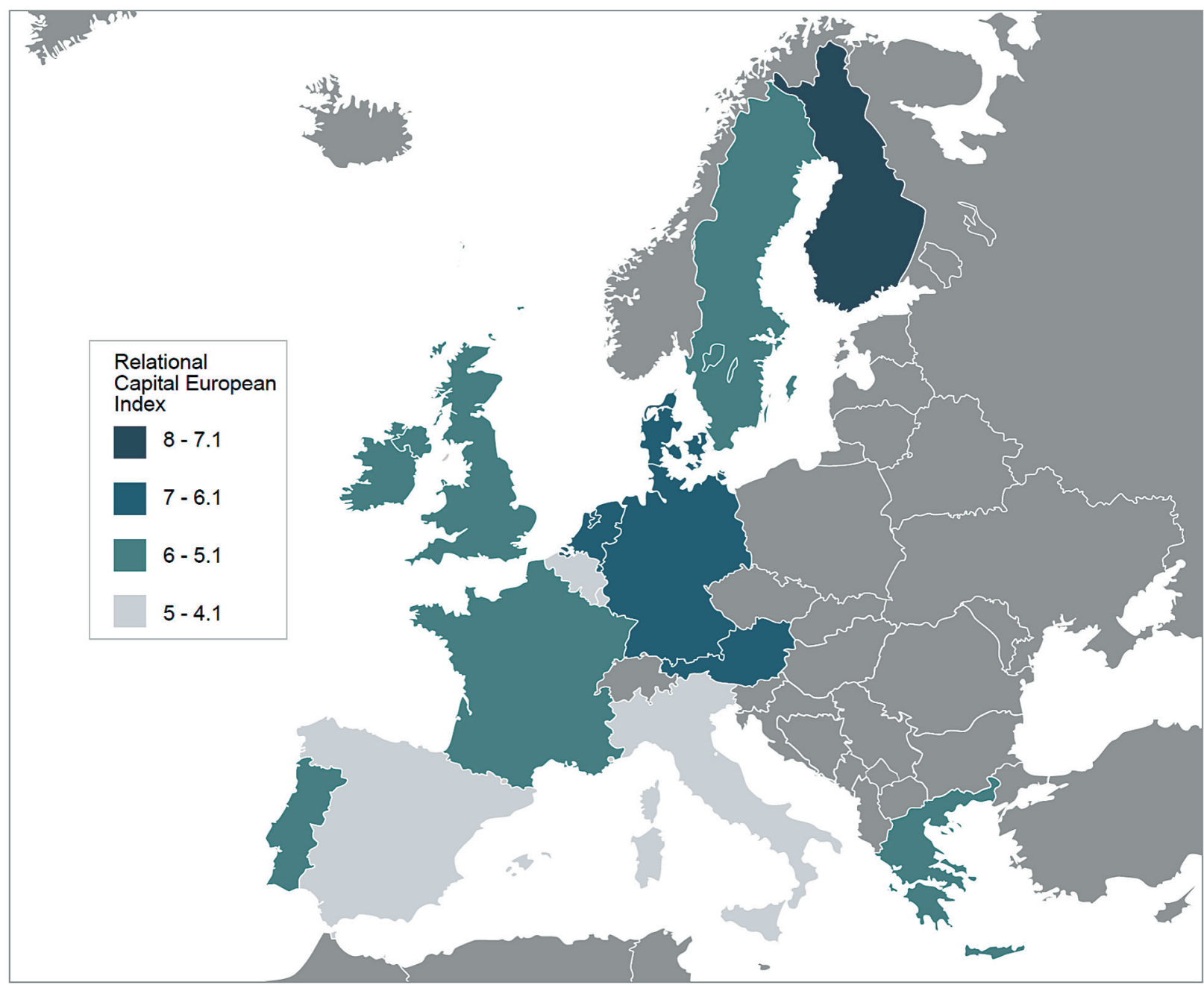

Fig. 4. Relational capital European index of the EU-15. Source: own elaboration. 
vious years. This indicator is a proxy of open innovation (relational capital 2).

\section{Results}

\subsection{Estimation model}

The results of the estimations of the model adopted relating to the innovation production function are shown in Table 4.

The results obtained for the estimation of formula (2) of the model referring to the innovation production function are presented in Table 4 . The first equation (2.1) is estimated considering that country-specific constants are randomised, obtaining the value of $\chi^{2}=14.87$, following Hausman (1978). In Table 4, the p-value for the Hausman test is $0.02<0.05$, i.e. the null hypothesis is accepted with random effects rejected, so fixed effects must be chosen. Therefore it is necessary to estimate the innovation production function and fixed effects shown in equation (2.2).

From the results obtained in equation (2.2), the following conclusions can be drawn:

A) Innovation can be reasonably explained by three key variables - human capital (tertiary education), technological capital, and relational capital (open innovation).

B) Technological capital factors play the most significant role in the generation of innovation with an estimated coefficient (elasticity) of 0.739 .

C) Human capital, in particular, was approximated using the values of tertiary education. This plays a significant role in the generation of innovation with an estimated coefficient (elasticity) of 0.204 .

D) Relational capital was approximated by the indicator of open innovation. This plays a significant role in the generation of innovation with an estimated coefficient (elasticity) of 0.135 .

To summarise, regions with lower barriers and more human, technological and relational capital have the characteristics required for innovation.

\section{Conclusions}

This study proposes the existence of a new driving mechanism of innovation generation based not only on the accumulation of knowledge, but also on collaborative relationships between universities, private companies, and public administration. The assumptions made in a theoretical model of innovation, for the case of the Europe of the Fifteen, are contrasted empirically. It examines the economic geography of human and technological capital in Europe, factors that define this geography, and the effects of each of them on innovation in the European countries. Definitely, this analysis has allowed us to contribute to unravelling the complex web of relationships between human, technological and relational capital and innovation, clarifying key aspects of the innovation model adopted.

The main conclusions of the modelling performed are as follows:

A) With our databases concerning European countries (the European Innovation Score-

Table 4. Estimation of the panel data (production function of innovation) (2003-2009).

\begin{tabular}{|c|c|c|c|}
\hline & & Innovation (random effects) & Innovation (fixed effects) \\
\hline \multicolumn{2}{|c|}{ Explanatory variables } & Equation 2.1 & Equation 2.2 \\
\hline \multicolumn{2}{|c|}{ Constant } & $-1.199(-3.068)$ & $-0.673(-1.8430)$ \\
\hline \multicolumn{2}{|c|}{ Human capital 1 (tertiary education) } & $0.246(2.628)$ & $0.204(2.247)$ \\
\hline \multicolumn{2}{|c|}{ Technological capital } & $1.008(5.591)$ & $0.739(3.919)$ \\
\hline \multicolumn{2}{|c|}{ Relational capital 2 (open innovation) } & $0.145(1.924)$ & $0.135(1.977)$ \\
\hline Observations & & 105 & 105 \\
\hline Statistic & $\mathrm{R}^{2}$ & - & 0.986 \\
\hline Hausman & $\chi_{(6)}^{2}$ & 14.87 & - \\
\hline p-value & $\mathrm{p}$ & 0.02 & - \\
\hline
\end{tabular}


board) we have found empirical evidence that human capital 1, particularly the core which we have called tertiary education, better predicts innovation than other non-traditional measures of talent based on university and non-university educational levels.

B) Collaborative relationships between universities, private companies and public administration are significantly associated with the generation of innovation.

C) The analysis shows that human, technological and relational capital factors have a positive and relevant role in the production of innovation. Collaborative relationships are beyond the market; however, they provide the link between innovation as an idea and its practical implementation. Certain regional conditions seem to play a significant role in the creation of an environment or habitat that could link human capital with technological capital, generating innovation. The three factors of human, technological and relational capital do not operate in competition with each other; instead, they tend to act by playing complementary roles in the economic growth process.

D) All these results lead us to the assertion that innovation in Europe is the result of a cumulative process that involves a combination of relational capital as identified by Jacobs, Florida, Clark and Glaeser, with the human capital externalities identified by Lucas, Romer and Glaeser, and the role of technological capital reported by Romer and Solow. However, relational capital is the factor which provides the impetus for the implementation of innovation.

Definitely, it should be concluded that innovation among the European countries appears within the process based on the following stages. In the first, institutional and non-market factors, such as collaborative relationships between universities, private companies and public administration, positively affect the production of human capital. In the second stage, the levels of human capital and technological capital generate technological innovation. Finally, in the third stage, higher levels of technological innovation lead to higher income levels. The effects corresponding to the human capital measures based on studies, especially the so-called tertiary studies, are higher than those based on educational levels.

Summing up, the results obtained indicate that the structure of relations between the discussed factors and innovation in the EU-15 countries is of great complexity. In this sense, it is highly relevant to conduct future in-depth investigations to further elucidate the numerous aspects treated in this work, which will allow us to advance in the knowledge of how those factors act on innovation in the European countries.

\section{References}

BARRO R.J., 1991. Economic growth in a cross section of countries. Quarterly Journal of Economics, 106(2): 407-443.

BerRy C.R. \& GLAESER E.L., 2005. The divergence of human capital levels across cities. NBER Working Paper No. 11617. University of Chicago, Chicago, IL.

Black D. \& Henderson V., 1998. A theory of urban growth. Journal of Political Economy, 107(2): 252-284.

Eaton J. \& Eckstein Z., 1997. Cities and growth: Theory and evidence from France and Japan. Regional Science and Urban Economics, 27(4-5): 443-474.

FloRIDA R., 2002a. The rise of the Creative Class. And how it's transforming work, leisure and everyday life. Basic Books, New York.

FLORIDA R., 2002b. The economic geography of talent. Annals of the Association of American Geographers, 92(4): 743-755.

FLoRIDA R., 2002c. Bohemia and economic geography. Journal of Economic Geography, 2: 55-71.

FloRIDA R., 2005a. Cities and the creative class. Routledge, New York.

FLORIDA R., 2005b. The flight of the creative class. Harper Business, New York.

FloRIDA R., 2006. Where the brains are. The Atlantic Monthly, 298(3): 34

Florida R., Mellander Ch. \& Stolarick K., 2010a. Talent, technology and tolerance in Canadian regional development. Canadian Geographer, 54(3): 277-304.

Florida R., Mellander CH. \& Stolarick K., 2010b. Music scenes to music clusters: The economic geography of music in the US, 1970-2000. Environment and Planning A, 42(4): 785-804.

Glaeser E.L., 1998. Are cities dying? Journal of Economic Perspectives, 12: 139-160.

GLAESER E.L., 1999. The future of urban research: Nonmarket interactions. Brookings Institutions, Washington, DC.

GLAESER E.L., 2000a. The new economics of urban and regional growth. In: Clark G., Gertler M. \& Feldman M. (eds), The Oxford handbook of economic geography. Oxford University Press, Oxford: 83-98.

Glaeser E.L., 2000b. Cities and ethics: An essay for Jane Jacobs. Journal of Urban Affairs, 22(4): 473-494.

Glaeser E.L., Sheinkman J.A. \& Sheifer A., 1995. Economic growth in a cross-section of cities. Journal of Monetary Economics, 36: 117-143.

Glaeser E.L., Kolko J. \& Saiz A., 2001. Consumer city. Journal of Economic Geography, 1: 27-50. 
GLENDON S., 1998. Urban life cycles. Working paper. Harvard University, Cambridge, MA.

JacoBs J., 1961. The death and life of great American cities. Random House, New York.

JacoBs J., 1969. The economies of cities. Random House, New York.

Hausman J., 1978. Specification test in econometrics. Econometrica, 46: 1251-1271.

LeYDESDORFF L., 2005. The Triple Helix Model and the study of knowledge-based innovation systems. International Journal of Contemporary Sociology, 42(1): 12-27.

LUCAS R.E., 1988. On the mechanics of economic development. Journal of Monetary Economics, 22(1): 3-42.

Mellander Ch. \& Florida R., 2011. Creativity, talent, and regional wages in Sweden. Annals of Regional Science, 46(3): 637-660.

RAUCH J.E., 1993. Productivity gains from geographic concentrations of human capital: Evidence from the cities. Journal of Urban Economics, 34(3): 380-400.

ROMER P.M., 1986. Increasing returns and long-run growth. Journal of Political Economy, 94(5): 1002-1037.

ROMER P.M., 1987. Crazy explanations of the productivity slowdown. NBER Macroeconomics Annual, 2: 163-202.

ROMER P.M., 1990. Endogenous technological change. Journal of Political Economy, 98(5): S71-S102.

Roth S., Wetzel R. \& Muller K., 2011. Editorial. Going beyond the hard core of innovation. Non-technological and non-economic dimensions of innovation systems. International Journal of Innovation and Regional Development, 3(1): 1-11.

SHAPIRO J.M., 2006. Smart cities: Quality of life, productivity, and the growth effects of human capital. Review of Economics and Statistics, 88(2): 324-335.

SIMON C., 1998. Human capital and metropolitan employment growth. Journal of Urban Economics, 43: 223-243.

Solow R.M., 1956. A contribution to the theory of economic growth. Quarterly Journal of Economics, 70(1): 65-94.

Solow R.M., 1957. Technical change and the aggregate production function. Review of Economics and Statistics, 39: 312-320.

Solow R.M., 1970. Growth theory: An exposition. Clarendon Press, Oxford.

Stolarick K. \& Florida R., 2006. Creativity, connections and innovation: A study of linkages in the Montreal Region. Environment and Planning A, 38(10): 1799-1817.

Young A., 1998. Growth without scale effects. Journal of Political Economy, 106(1): 41-63.

Warren L., Kitagawa F. \& Eatough M., 2010. Developing the knowledge economy through university linkages. An exploration of RDA strategies through case studies of two English regions. International Journal of Entrepreneurship and Innovation, 11(4): 293-306. 